\title{
Aboriginal Health-The Overlap Among Child Maltreatment, Mental Health, and Addictive Behaviours-The Way Forward
}

\author{
Marlyn Bennett • Christine Wekerle • Masood Zangeneh
}

Published online: 2 April 2010

(C) Springer Science+Business Media, LLC 2010

Developing community systems of services for Aboriginal children and youth in care with special health care needs and/or addiction and mental health needs represent a significant challenge for families, communities, pediatricians as well public and private agencies providing services to these populations. At the provincial level, First Nations child and family service agencies are vested with the responsibility of planning and developing systems of care for children with special health needs who may come into contact with the child welfare system. However, during the last half-century, service systems have become increasingly complex as a result of health, education, and social policy changes, as well as changes in the epidemiology of child health, including increases in the number and proportion of Aboriginal children coming into the child welfare system with chronic conditions and disabilities (Bennett and Blackstock 2007). These changes have resulted in gaps in many service areas (both health and child welfare related) as well as fragmentation in the way service systems are organized and accessed (Shangreaux 2004).

For First Nations children living in First Nations communities, in particular, access to services for health related matters, is simply not available in their communities and depending upon their circumstances, many are voluntarily placed into child welfare care so they can access the services they need to address physical, mental and or addiction related needs (Lavallee 2005). Very little research exists within Canada about the nature and extent of the incidence of First Nations children with special needs (i.e. physical, cognitive, learning,

M. Bennett

First Nations Child \& Family Caring Society of Canada, Winnipeg, MB, Canada

C. Wekerle

Department of Pediatrics HSC 3A, CAAP 3N10, McMaster University, 1200 Main Street. W., Hamilton, ON L8N 3Z5, Canada

e-mail: cwekerle@uwo.ca

C. Wekerle

The University of Western Ontario, London, ON, Canada

M. Zangeneh $(\bowtie)$

International Journal of Mental Health \& Addiction, Toronto, ON, Canada

e-mail: masood.zangeneh@gmail.com 
mental or addiction related), particularly within a child welfare environment. Furthermore, the existing research does not appear to address the importance of addressing the service gaps to First Nations children with special needs who may be in the care of either Aboriginal and/or non-Aboriginals systems of government care (Wright et al. 2005).

There are substantial knowledge gaps in health and child welfare services to First Nations children and families with special needs, disabilities, mental health and addiction concerns. The starting point for this International Journal of Mental Health and Addiction's Aboriginal Health Special Issue was a Canadian Institutes for Health Research-funded knowledge translation conference where the lead organizers were the First Nations Child and Family Caring Society (www.fncfcs.com), partnering with university academics, and delivering evidence-based research to the Aboriginal community in Winnipeg, Manitoba, Canada.

This conference was initiated by the life — and death — of an Aboriginal child who did not live one day in his home on reserve, despite being medically cleared for his special needs. The federal and provincial negotiations outlived little Jordan's life. A press to put children first developed into an initiative called Jordan's Principle (see First Nations Child and Family Caring Society website). The Canadian research needs that needed to be addressed were identified at this conference. These include:

(1) The incidence of First Nations children with special needs (physical, cognitive, mental health and/or addictions) particularly within a child welfare environment;

(2) Service gaps for First Nations children in care with special needs in both the onreserve and off-reserve context;

(3) Service gaps to First Nations children with special needs (FASD/disabilities) in care and in the efficacy of differential response models to address these needs; ${ }^{1}$

(4) Understanding mental health issues for First Nations families and/or children that become involved with First Nations child and family service agencies;

(5) Treatment programs for First Nations families and youth with addiction issues who are involved with child welfare;

(6) Educational approaches to understanding the issues and challenges of First Nations families and children dealing with special needs (health and disabilities), mental health and addiction issues when involved with the child welfare system;

(7) Showcasing innovative child welfare and health partnership initiatives with First Nations populations both on and off reserve.

Beyond this conference, International Journal of Mental Health and Addiction sent out a public notice for the special issue and invited submissions. The final product is a combination of those authors who responded to this invitation and authors who presented at the Canadian "Bridging the Gaps" conference.

As a guest editorial group, we determined it important to follow Canadian CIHR Guidelines for research with Aboriginal Peoples, and ensure that each article included authorship of an Aboriginal practitioner, policy-maker, or scientist. We are enthusiastic about the future scholarship as more Indigenous researchers are initiating a wide range of culturally competent and appropriate - hence, culturally safe — research projects. We need new knowledge and new researchers. Together, in this issue, we have a chance to learn and

\footnotetext{
${ }^{1}$ The Differential Response service model (Wekerle, Leung, Waechter \& Chen, 2010) provides an alternate investigative response that is more customized and less adversarial in approach to reports received by a CAS rated moderate to low in severity while maintaining the importance of the child's safety and well-being as a first priority.
} 
discuss the issues and challenges around health and child welfare service gaps particularly as it affects First Nations families and children dealing with special needs (i.e. physical, cognitive, learning, mental or addiction related) when faced with a family crisis. Our ultimate goal is universal, a human rights perspective that supports the health of the populace.

We hope that this journal is a beginning to a way moving forward. We thank all contributors and the anonymous reviewers for the time and efforts. Moving forward, we hope to continue to achieve important objectives to science-based advocacy and evidencebased practice and policy. These issues remain for our continued joint attention:

- Increase knowledge on why and where service gaps exist across many service sectors;

- Better understanding of the challenges faced by families who have children with special needs, disabilities, mental health or addiction issues;

- Better understanding of the issues and the challenges faced by the health sector in servicing First Nations children with special needs, disabilities, mental health or addition issues;

- Increase knowledge on the issues and challenges faced by the child welfare system in servicing children and families grappling with special needs, disabilities, mental health or addiction issues;

- Assist in a paradigm shift of thinking toward collaborative practices on how child welfare and health services systems can best begin working together to fill gaps in services to First Nations children;

- Become involved in building a network of researchers who may, in the long term, work toward a more permanent network dedicated to more cross-sectional/collaborative approaches in addressing the service gaps to First Nations children across the child welfare and health service sectors;

\section{Contributors}

Marlyn Bennett, M.A.

Director of Research, First Nations Child \& Family Caring Society of Canada

Cindy Blackstock, $\mathrm{PhD}$.

Director, First Nations Child and Family Caring Society of Canada

http://www.oasw.org/en/publicsite/aboutworkers/cblackstock.asp

Brock Boudreau

Dalhousie University, Halifax, Canada

Linda Burnside, Ph.D.

University of Manitoba, Canada

Marilyn Van Bibber

Qualicum Beach, British Columbia, Canada

Dave Clarke, Ph.D.

Senior Lecturer, School of Psychology, Massey University, New Zealand

http://www.massey.ac.nz/ psyweb/staff/dclarke.htm 
Debbie Chiodo, M.A., M.ED.

Lecturer, University of Western Ontario

Centre Manager and Researcher, CAMH Centre for Prevention Science, Canada

http://www.youthrelationships.org/program_directors.html\#debbie

Claire V. Crooks, Ph.D.

Associate Director, CAMH Centre for Prevention Science

Adjunct Professor, University of Western Ontario, Canada

http://www.youthrelationships.org/program_directors.html\#claire

Delphine Collin-Vézina

Social Work Department

McGill University, Montreal, Canada

Mike Campeau

Cree Nation Tribal Health, Swampy Cree Tribal Council, the Pas, Manitoba, Canada

http://www.suicideresearch.ca/about_community_mike.asp

Emilie Cameron, Ph.D.

Department of Geography, Queen's University, Kingston, Canada

http://emiliecameron.wordpress.com/

M. Nancy Comeau, Ph.D.

Adjunct Professor, School of Health and Human Performance,

Faculty of Health Professions, Cape Breton University

Department of Psychology, Dalhousie University, Halifax, Canada

Sharon Clarke

McMaster University, Hamilton, Canada

David N. Cox

Department of Psychology, Simon Fraser University, Burnaby, Canada

Jacinthe Dion

Department of Education and Psychology

University of Québec at Chicoutimi, Canada

Mireille De La Sablonnière

Social Work Department

McGill University, Montreal, Canada

Lorna Dyall, Ph.D.

Te Kupenga Hauora Maori, University of Auckland, New Zealand

Sarah de Leeuw, $\mathrm{PhD}$

Northern Medical Program, University of Northern British Columbia, Prince George, Canada

Colleen Anne Dell, Ph.D.

McMaster University, Hamilton, Canada 
Maureen Dobbins, Ph.D.

McMaster University, Hamilton, Canada

http://fhs.mcmaster.ca/nursing/faculty_dobbins.shtml

Dennis M. Donovan, Ph.D.

University of Washington Alcohol and Drug Abuse Institute, Seattle, USA

http://depts.washington.edu/adai/staff/donovanbio.htm

Erin Ebbett, M.A.

School of Psychology, Massey University, New Zealand

Brenda Elias, Ph.D.

Department of Community Health Sciences, University of Manitoba, Canada

http://www.suicideresearch.ca/about_university_brendan.asp

Murray W. Enns, M.D.

Department of Psychiatry, University of Manitoba, Winnipeg, Canada

http://www.suicideresearch.ca/about_university_murray.asp

Don Fuchs, Ph.D.

Professor, Faculty of Social Work, University of Manitoba, Canada

http:/www.umanitoba.ca/centres/aging/people/144.htm

Judy Finlay

Associate Professor, School of Child \& Youth Care, Ryerson University, Canada http://www.ryerson.ca/news/news/Research_News/20070914_JudyFinlay.html

Tania Giffard

Department of Psychology, Université de Trois-Rivières, Trois-Rivières, Canada

Margo Greenwood, PhD

Assistant Professor

National Collaborating Centre for Aboriginal Health, University of Northern British Columbia,

Prince George, Canada

Joanna Henderson

McMaster University, Hamilton, Canada

Micheal Hardy

Executive Director/Local Director, Tikinagan Child \& Family Services, Sioux Lookout, Canada

http://www.oasw.org/en/publicsite/aboutworkers/mhardy.asp

Ray Hughes, M.Ed.

National Education Coordinator for the Fourth R Project, CAMH Centre for Prevention Science

Instructor, Safe Schools at the Faculty of Education, University of Western Ontario, Canada http://www.youthrelationships.org/program_directors.html\#ray 
Corinne A. Isaak, M.Sc.

Research Associate

Department of Psychiatry, University of Manitoba, Winnipeg, Canada

http://www.suicideresearch.ca/about_members_corinne.asp

Laurence Y. Katz, M.D.

Department of Psychiatry, University of Manitoba, Winnipeg, Canada

http://www.suicideresearch.ca/about_university_laurence.asp

Andrew Kmetic, Ph.D.

Department of Psychology, Simon Fraser University, University Drive, Burnaby, Canada

Lynn F. Lavallee, Ph.D.

Assistant Professor, Ryerson University, Toronto, Canada

http://www.ryerson.ca/socialwork/faculty/bios/lavallee.html

Maria Marama

University of Auckland, New Zealand

Donny Morris

Chief, Kitchenuhmaykoosib Inninuwug, Thunder Bay, Canada

Sheila Marchenski, Ph.D.

University of Manitoba, Winnipeg, Canada

Andria Mudry, Ph.D.

University of Manitoba, Winnipeg, Canada

Christopher J. Mushquash

Department of Psychology, Dalhousie University, Halifax, Canada

Brian D. McLeod

Dalhousie University, Halifax, Canada

Karen Milligan

McMaster University, Hamilton, Canada

Anna Nagy

Department of Psychology, University of Toronto at Scarborough, Canada

Alison Niccols, $\mathrm{PhD}$

McMaster University, Hamilton, Canada

http://fhs.mcmaster.ca/psychiatryneuroscience/faculty/niccols/

Melanie Noel, M.Sc.

Dalhousie University, Halifax, Canada

http://pedpsych.psychology.dal.ca/researchers/Melanie.html 
Roisin M. O'Connor, Ph.D.

Dalhousie University, Halifax, Canada

Marie-Pierre Philippe-Labbé

University of Québec at Chicoutimi, Canada

Jennifer M. Poole, Ph.D.

Assistant Professor, Ryerson University, Toronto, Canada

http://www.ryerson.ca/socialwork/faculty/bios/poole.html

Jeff Reading

Department of Psychology, Simon Fraser University, University Drive, Burnaby, Canada

Deborah Rutman, Ph.D.

School of Social Work, University of Victoria, Victoria,

British Columbia, Canada

Jitender Sareen, M.D.

Departments of Psychiatry, Community Health Sciences and Psychology, University of Manitoba, Canada

http://www.suicideresearch.ca/about_university_jitender.asp

Sherry H. Stewart, $\mathrm{PhD}$

Professor of Psychiatry, Psychology, and CH\&E

Dalhousie University, Halifax, Canada

http://experts.dal.ca/expertfile.cfm?EmployeeID $=22$

Wendy Sword, Ph.D.

McMaster University, Hamilton, Canada

http://fhs.mcmaster.ca/nursing/faculty_sword.shtml

Ainsley Smith

McMaster University, Hamilton, Canada

Doreen Stevens

Department of Psychology, Mount Saint Vincent University, Halifax, Canada

Robin L. W. Sigo

Suquamish Tribe, Suquamish, USA

Andrew Snowball

Factor-Inwentash Faculty of Social Work, University of Toronto, Canada

Darren Thomas

Bear Clan from the Haudenosaunee (Seneca Nation)

Coordinator of Community Service-Learning, Wilfrid Laurier University, Canada

http://www.youthrelationships.org/researchers_staff.html\#darren 
Lisa Rey Thomas, Ph.D.

University of Washington Alcohol and Drug Abuse Institute, Seattle, USA

http://depts.washington.edu/adai/staff/thomasbio.htm

Lil Tonmyr, Ph.D.

Public Health Agency of Canada, Ottawa, Canada

Michael Ungar, Ph.D.

School of Social Work, Dalhousie University, Halifax, Canada

http://socialwork.dal.ca/Faculty\%20and\%20Staff/Faculty/Michael_Ungar.php

Kimberly A. van der Woerd, Ph.D.

Department of Psychology, Simon Fraser University, University Drive, Burnaby, Canada http://www.fin.gov.bc.ca/BRDO/memView.asp?Member=217273

Cynthia C. Wesley-Esquimaux, Ph.D.

Assistant Professor, Centre for Aboriginal Initiatives and the Factor Inwentash Faculty of Social Work,

University of Toronto, Canada

http://www.socialwork.utoronto.ca/faculty/bios/esquimaux.htm

Christine Wekerle, Ph.D.

Associate Professor, Faculty of Education, University of Western Ontario, Canada http://publish.edu.uwo.ca/christine.wekerle/

Marc Zahradnik

Psychology, Dalhousie University, Halifax, Canada

\section{References}

Bennett, M., \& Blackstock, C. (Fall 2007). Aboriginal Child Welfare in Canada: Understanding the overrepresentation and empowering opportunities through reconciliation in child welfare. Canada's Children, Fall 2007. Ottawa, ON: Child Welfare League of Canada. http://www.cwlc.ca/files/file/Canada $\% 27 \mathrm{~s} \% 20$ Children/CC\%20Fall\%202007.pdf.

Lavallee, T. L. (2005). Honouring Jordan: Putting First Nations children first and funding fights second. Journal of Paediatrics and Child Health, 10, 527-529. Retrieved September 3, 2007 from: http://www. pulsus.com/Paeds/10_09/Pdf/lava_ed.pdf.

Shangreaux, C. (2004). Staying at home: Examining the implications of least disruptive measures in First Nations Child and Family Service Agencies. Ottawa: First Nations Child \& Family Caring Society of Canada. Accessed from http://www.fncfcs.com/docs/Staying_at_Home.pdf.

Wekerle, C., Leung, E., Waechter, R., \& Chen, M. (2010). Looking to the Future: Child Welfare (Chapter 6). Ontario: Ministry of Child and Youth Services.

Wright, A., Hiebert-Murphy, D., \& Gosek, G. (2005). Supporting aboriginal children and youth with learning and/or behavioural disabilities in the care of aboriginal child welfare agencies. Winnipeg, MB: First Nations Child and Family Caring Society of Canada. Accessed from http://www.fncaringsociety. org/docs/SupportingAboriginalChildren.pdf. 